\title{
Performance and metabolic profile of dairy cows during a lactational and deliberately induced negative energy balance with subsequent realimentation
}

\author{
J. Gross, ${ }^{*}$ H. A. van Dorland,† R. M. Bruckmaier,† and F. J. Schwarz*1 \\ *Department of Animal Sciences, Chair of Animal Nutrition, Technical University of Munich, Liesel-Beckmann-Str. 6, \\ D-85350 Freising-Weihenstephan, Germany \\ †Veterinary Physiology, Vetsuisse Faculty, University of Bern, Bremgartenstr. 109a, CH-3001 Bern, Switzerland
}

\begin{abstract}
Homeorhetic and homeostatic controls in dairy cows are essential for adapting to alterations in physiological and environmental conditions. To study the different mechanisms during adaptation processes, effects of a deliberately induced negative energy balance (NEB) by feed restriction near $100 \mathrm{~d}$ in milk (DIM) on performance and metabolic measures were compared with lactation energy deficiency after parturition. Fifty multiparous cows were studied in 3 periods $(1=$ early lactation up to 12 wk postpartum; 2 = feed restriction for 3 wk beginning at $98 \pm 7$ DIM with a feed-restricted and control group; and $3=$ a subsequent realimentation period for the feed-restricted group for $8 \mathrm{wk}$ ). In period 1, despite NEB in early lactation [-42 MJ of net energy for lactation $\left(\mathrm{NE}_{\mathrm{L}}\right) / \mathrm{d}$, wk 1 to 3 ] up to wk 9 , milk yield increased from $27.5 \pm 0.7 \mathrm{~kg}$ to a maximum of $39.5 \pm 0.8 \mathrm{~kg}$ (wk 6). For period 2, the NEB was induced by individual limitation of feed quantity and reduction of dietary energy density. Feed-restricted cows experienced a greater NEB (-63 MJ of $\left.\mathrm{NE}_{\mathrm{L}} / \mathrm{d}\right)$ than did cows in early lactation. Feed-restricted cows in period 2 showed only a small decline in milk yield of $-3.1 \pm 1.1 \mathrm{~kg}$ and milk protein content of $-0.2 \pm 0.1 \%$ compared with control cows $(30.5 \pm 1.1 \mathrm{~kg}$ and $3.8 \pm$ $0.1 \%$, respectively). In feed-restricted cows (period 2), plasma glucose was lower $(-0.2 \pm 0.0 \mathrm{mmol} / \mathrm{L})$ and nonesterified fatty acids higher $(+0.1 \pm 0.1 \mathrm{mmol} / \mathrm{L})$ compared with control cows. Compared with the NEB in period 1, the decreases in body weight due to the deliberately induced NEB (period 2) were greater (56 \pm 4 vs. $23 \pm 3 \mathrm{~kg}$ ), but decreases in body condition score $(0.16 \pm 0.03$ vs. $0.34 \pm 0.04)$ and muscle diameter $(2.0 \pm 0.4$ vs. $3.5 \pm 0.4 \mathrm{~mm})$ were lesser. The changes in metabolic measures in period 2 were marginal compared with the adjustments directly after parturition in
\end{abstract}

Received August 10, 2010.

Accepted December 22, 2010.

${ }^{1}$ Corresponding author: schwarzf@wzw.tum.de period 1. Despite the greater induced energy deficiency at 100 DIM than the early lactation NEB, the metabolic load experienced by the dairy cows was not as high as that observed in early lactation. The different effects of energy deficiency at the 2 stages in lactation show that metabolic problems in early lactating dairy cows are not due only to the NEB, but mainly to the specific metabolic regulation during this period.

Key words: negative energy balance, dairy cow, performance, metabolic parameter

\section{INTRODUCTION}

The onset of lactation in dairy cows is accompanied by low DMI and low energy availability, both of which slowly increase during the first week postpartum. During the same period, milk production steeply increases. Consequently, the energetic requirements of the early lactating cow are not met by her energy intake. This status is called a negative energy balance (NEB), and is described in most studies of newly lactating cows except those of Kessel et al. (2008) and van Dorland et al. (2009). A more adequate term that Butler et al. (2003) proposed might be "lactation-induced NEB" as this situation occurs naturally after calving and depends on the amount of milk yield and simultaneous DMI. The NEB in early lactation can be accompanied by health disorders (Bertoni et al., 2009).

Negative energy balance is associated with mobilization of body reserves, predominantly localized in fat and muscle tissue, because of homeorhetic control with highest priority for nutrient partitioning toward the mammary gland (Bauman and Currie, 1980). The priority of milk production after parturition is expressed by increased milk yield despite the physiological NEB. Plasma NEFA and ketone body concentrations increase during this early lactation stage and peak before maximum milk yield. The lactation-induced NEB may last up to 14 wk of lactation, whereas the peak of milk yield is found between wk 4 and 8 postpartum (NRC, 2001). 
An NEB may occur later in lactation during insufficient supply and quality of feed. This is seen in pastured high-yielding dairy cows and in dairy cows fed a TMR without taking into account the different performance levels and individual requirements of the cow. In this respect, energy density of the diet can be a limiting factor affecting performance. In these situations, dairy cows need to adapt to maintain homeostasis. Homeostasis is the property that regulates the internal environment and tends to maintain a stable physiological condition (Cannon, 1929; Bauman and Currie, 1980), such as the established lactation after the NEB period; that is, in mid lactation or in the so-called production phase of lactation, during which the metabolic priority of the mammary gland no longer exists. Induced NEB at this stage of lactation resulted in a decreased milk yield with elevated NEFA concentration (Carlson et al., 2006).

Performance and physiological reactions in dairy cows are influenced by homeorhetic and homeostatic control. To our knowledge, studies of homeorhetic and homeostatic control in early and mid lactation have not yet been carried out. Therefore, the objective of this study was to quantify and compare the performance and physiological reactions in dairy cows during NEB in early lactation and a deliberately induced NEB by feed restriction following early lactation. The hypothesis tested was that performance is differently affected by a marked NEB during homeorhetic and homeostatic control in dairy cows.

\section{MATERIALS AND METHODS}

Animal experiments were carried out at the Agricultural Experimental Unit Hirschau of the Technical University of Munich, Germany, and were approved by the responsible department for animal welfare affairs.

\section{Animals}

Fifty multiparous Holstein dairy cows $(3.2 \pm 0.2$ parities, mean \pm SEM) were studied from wk 1 prepartum to about wk 26 postpartum. The lactating herd was housed in a freestall barn. From $10 \mathrm{~d}$ before expected calving until d 5 postpartum, animals were fed individually in calving pens with straw bedding.

Period 1 was wk 1 prepartum to 12 postpartum, where all animals were treated as one group. In period 2 , animals were allocated equally to either a control group $(\mathbf{C}, \mathrm{n}=25)$ or a restriction group $(\mathbf{R}, \mathrm{n}=25)$ according to the extent of NEB the cows experienced in period 1. The restriction phase (period 2) lasted for 3 wk and started at $98 \pm 7$ DIM. The week before feed restriction was classified as wk 0 , where all cows were treated as one group. After 3 wk of feed restriction, period 3 started and lasted for $8 \mathrm{wk}$, during which $\mathrm{R}$ cows were (re)fed similarly to $\mathrm{C}$ cows (realimentation period).

\section{Feeding Regimen}

Animals in period 1 received a partial mixed ration 1 (PMR 1, Table 1) for ad libitum intake of basic feed (silages, hay) with separate and limited intake of concentrates. The PMR 1 was calculated to meet the demands for energy and protein of a cow $(650 \mathrm{~kg}$ of BW) producing $21 \mathrm{~kg}$ of milk/d with an assumed DMI of $16 \mathrm{~kg}$ of $\mathrm{DM} / \mathrm{d}$. The PMR 1 was given once daily at 0930 h. Feed bins for recording individual PMR intake were connected to electronic balances. In addition to PMR 1, concentrate (CONC, Table 1) was fed at 1.3 $\mathrm{kg}$ of $\mathrm{DM} / \mathrm{d}$ for the first $5 \mathrm{~d}$ of lactation. On d 6 postpartum, cows received $1.8 \mathrm{~kg} \mathrm{DM}$ of $\mathrm{CONC} / \mathrm{d}$, which was increased up to $8.9 \mathrm{~kg} \mathrm{DM} / \mathrm{d}$ in the following 35 d. Thereafter, CONC was fed according to individual extra requirements for milk production. The CONC was offered in transponder-access feeding stations by an automatic feeding program (DeLaval Alpro, Glinde, Germany). Calculations for energy and protein supply followed the recommendations of the German Society of Nutrition Physiology (GfE, 2001).

At the start of period 2, $\mathrm{R}$ cows received PMR 1 with additional hay to reduce the energy content (PMR 2, Table 1). Furthermore, CONC was limited to $0.4 \mathrm{~kg} \mathrm{DM} / \mathrm{d}$ for all $\mathrm{R}$ cows during period 2. The amount of PMR 2 was limited in each week of period 2 to maintain an energy deficiency of a least $30 \%$ of the calculated requirements. Consequently, the protein supply was reduced correspondingly to obtain a stable energy:protein ratio. The $\mathrm{C}$ cows were maintained on PMR 1 ad libitum as in period 1 . In period $3, \mathrm{R}$ cows had free access to PMR 1 until the end of the study. The CONC was set from 0.4 to $4.5 \mathrm{~kg} \mathrm{DM} / \mathrm{d}$ (the mean value of the $\mathrm{C}$ group) in wk 1 of realimentation. During the remainder of period 3, CONC was adapted weekly for all animals as described above. For each cow, daily DMI (PMR and CONC) was recorded continuously. Changes of the diets were carried out all at once within a day. All animals had free access to fresh water.

\section{Feed Samples and Analyses}

Samples of all forages and CONC were collected weekly; samples of PMR 1 and PMR 2 were obtained twice per week. For analysis of DM, fresh feeds were weighed, dried for $24 \mathrm{~h}$ at $60^{\circ} \mathrm{C}$, and reweighed. Sam- 
Table 1. Composition and nutrient values of experimental diets and concentrate (CONC)

\begin{tabular}{|c|c|c|c|}
\hline \multirow[b]{2}{*}{ Item } & \multicolumn{2}{|c|}{ Partial mixed ration ${ }^{1}$} & \multirow[b]{2}{*}{$\mathrm{CONC}^{2}$} \\
\hline & PMR 1 & PMR 2 & \\
\hline \multicolumn{4}{|l|}{ Components (\% in DM) } \\
\hline Grass silage & 33.7 & 21.8 & \\
\hline Corn silage & 44.9 & 29.1 & \\
\hline Hay & 6.5 & 39.4 & \\
\hline Concentrate $^{3}$ & 14.9 & 9.7 & \\
\hline \multicolumn{4}{|l|}{ Nutrient values } \\
\hline Energy $^{4}\left(\mathrm{MJ}\right.$ of $\mathrm{NE}_{\mathrm{L}} / \mathrm{kg}$ of $\left.\mathrm{DM}\right)$ & 6.53 & 6.24 & 7.96 \\
\hline Crude fiber $(\mathrm{g} / \mathrm{kg}$ of $\mathrm{DM})$ & 214 & 251 & 62 \\
\hline Crude ash $(\mathrm{g} / \mathrm{kg}$ of $\mathrm{DM})$ & 76 & 75 & 76 \\
\hline Crude fat $(\mathrm{g} / \mathrm{kg}$ of $\mathrm{DM})$ & 32 & 28 & 24 \\
\hline $\mathrm{CP}(\mathrm{g} / \mathrm{kg}$ of $\mathrm{DM})$ & 146 & 138 & 216 \\
\hline $\operatorname{ADF}(\mathrm{g} / \mathrm{kg}$ of $\mathrm{DM})$ & 254 & 313 & 84.1 \\
\hline NDF $(\mathrm{g} / \mathrm{kg}$ of $\mathrm{DM})$ & 431 & 529 & 184 \\
\hline Lignin $(\mathrm{g} / \mathrm{kg}$ of $\mathrm{DM})$ & 23.6 & 32.4 & 3.9 \\
\hline $\mathrm{NFC}^{4,5}(\mathrm{~g} / \mathrm{kg}$ of DM$)$ & 316 & 230 & 500 \\
\hline Available $\mathrm{CP}^{4}(\mathrm{~g} / \mathrm{kg}$ of $\mathrm{DM})$ & 143 & 137 & 172 \\
\hline Ruminal $\mathrm{N}$ balance ${ }^{4}(\mathrm{~g} / \mathrm{kg}$ of $\mathrm{DM})$ & 0.88 & 0.18 & 2.37 \\
\hline
\end{tabular}

${ }^{1}$ PMR 1 was calculated to meet the demands for energy and protein of a cow (650 kg of BW) producing $21 \mathrm{~kg}$ of milk/d with an assumed DMI of $16 \mathrm{~kg}$ of DM/d; PMR $2=\mathrm{PMR} 1$ with additional hay to reduce the energy content and fed to restricted cows in period 2.

${ }^{2}$ Additional concentrate provided according to milk yield, consisting of (\% in DM) $14.9 \%$ barley, $24.8 \%$ corn kernels, $21.8 \%$ wheat, $20.1 \%$ soybean meal, $15.2 \%$ dried sugar beet pulp with molasses, and $3.2 \%$ vitaminmineral premix including limestone.

${ }^{3}$ Concentrate (\% in DM): $7.9 \%$ barley, $24.7 \%$ wheat, $60.0 \%$ soybean meal, $7.3 \%$ vitamin-mineral premix including salt and limestone.

${ }^{4}$ Calculated values.

${ }^{5}$ Calculated by difference: $100-(\% \mathrm{CP}+\% \mathrm{NDF}+\%$ crude fat $+\%$ crude ash $)$.

ples were milled (Brabender, Duisburg, Germany; filter width $1.1 \mathrm{~mm}$ ) and mixed into 2-wk sample pools (a 4-wk sample was pooled for CONC) for further analyses. Feed samples were analyzed for crude ash, crude fiber, and crude fat according to Weende analysis (Naumann et al., 2000). Crude protein $(\mathrm{N} \times 6.25)$ content was determined by Dumas method, and NDF, ADF, and lignin were analyzed according to Naumann et al. (2000). Net energy $\left(\mathrm{NE}_{\mathrm{L}}\right)$ and available $\mathrm{CP}$ at the duodenum (ACP) of the feed samples were calculated according to the German Society of Nutrition Physiology (GfE, 2001).

\section{BW, BCS, and Ultrasonographic Measurements}

Body weight was recorded automatically on electronic scales mounted in the concentrate feeders. Body condition was scored according to Edmonson et al. (1989) on a scale of 1 to 5 ( $1=$ thin, $5=$ obese $)$. Simultaneously, B-mode ultrasonographic measurements of the longissimus dorsi muscle diameter (MD) and backfat thickness (BFT) were performed as specified in Bruckmaier et al. (1998a). The MD and BFT were evaluated graphically according to Bruckmaier et al. (1998b) using Adobe Photoshop CS4 Extended (Adobe Systems Inc., San
Jose, CA). The BCS and ultrasonic measurements were performed at the same time by the same person.

\section{Milk and Blood Samples}

Cows were milked twice daily in a $2 \times 6$ milking parlor (DeLaval) at 0500 and 1500 h. Daily milk yield was recorded electronically. During the colostrum period or treatment of mastitis, the harvested milk was separated and manually weighed. Milk samples (about $50 \mathrm{~mL}$ ) were collected beginning at $3 \mathrm{~d}$ postpartum twice weekly on 2 consecutive milkings each (Monday p.m., Tuesday a.m., Thursday p.m., and Friday a.m.). Average fat, protein, and lactose concentrations were determined by an infrared analyzer (MilkoScan FT-6000, Foss Analytical A/S, Hillerød, Denmark; Milchprüfring Bayern e.V., Wolnzach, Germany).

Blood samples were collected weekly; sampling was performed after milking before feeding between 0730 and $0900 \mathrm{~h}$. Blood was collected via jugular puncture in $2 \mathrm{~K}_{3}$ EDTA-coated $(18 \mathrm{~mL})$ evacuated tubes (Greiner, Frickenhausen, Germany). Samples were cooled on wet ice, centrifuged at 2,000 $\times g$ for $15 \mathrm{~min}$, and the plasma was aliquoted into 1.5-mL Eppendorf tubes, and stored at $-20^{\circ} \mathrm{C}$ until analysis. 


\section{Energy and Protein Balance Calculations}

Energy balance was calculated for each cow individually as the difference between energy intake through feed and energetic output for maintenance and milk production. Energy intake was determined by multiplying average weekly DMI of PMR 1, PMR 2, and CONC with the corresponding $\mathrm{NE}_{\mathrm{L}}$ values. Maintenance requirement was quantified according to GfE (2001) by using the average weekly BW of the animal. Milk energy output resulted from milk yield and contents of mean fat, protein, and lactose of $1 \mathrm{wk}$ samples according to GfE (2001). Mobilization or deposition of body tissue, in cases of negative and positive energy balance, respectively, were not accounted for in the calculations. The ACP at the duodenum $(\mathrm{g} / \mathrm{d})$ was calculated for each cow individually as the difference between protein intake through feed and protein output for maintenance and milk production according to GfE (2001).

\section{Blood Plasma Metabolites}

Concentration of glucose was measured using a kit from bioMérieux (Geneva, Switzerland; no. 61269); of NEFA with kit no. FA 115, and of BHBA with kit no. RB 1007 (both from Randox Laboratories Ltd., Schwyz, Switzerland).

\section{Animal Health}

Occurrences of diseases and health disorders, detected by daily animal inspections with veterinarian assistance, were documented and assigned to one of the following classes: mastitis and other udder-related problems, reproductive tract and related problems, claw problems, or milk fever.

\section{Statistical Analysis}

Data presented are means \pm SEM. First, to evaluate the effect of the deliberately induced NEB at 100 DIM, performance and metabolic data from the control and treatment groups in period 2 and 3 were compared using the MIXED procedure of SAS (version 9.2, SAS Institute, Cary, NC). The model included week, group, lactation number, and week $\times$ group interaction as fixed effects. The area under the curve (AUC) of the respective measures from wk 1 to 12 postpartum was included additionally as a co-variable. The repeated subject was the individual cow. The differences between the $\mathrm{R}$ and $\mathrm{C}$ groups over time were detected by the Bonferroni $t$-test.

Second, the reactions of cows to the NEB in period 1 were compared with the reactions in period 2. This comparison was performed based on AUC differences/ week $(\triangle \mathrm{AUC} / \mathrm{wk})$ calculated for each period from the cows experiencing NEB (period 1, wk 1 to 3 postpartum; period 2, R cows) and during the time they did not (period 1, wk 1 prepartum; period 2, C cows). The calculated $\triangle \mathrm{AUC} /$ wk for the measured traits in periods 1 and 2 were statistically compared by using the MIXED procedure of SAS with period and lactation number as fixed effects and the individual cow as repeated subject. The differences between the periods were detected by the Bonferroni $t$-test; $P$-values $<0.05$ were considered significant.

Third, for the statistical analysis of occurrence of health disorders, a 1-sample binomial test was used to evaluate the differences between the 2 groups.

\section{RESULTS}

\section{Feed Intake and Energy Balance}

In period 1, mean total DMI (Figure 1A) increased weekly from $14.9 \pm 0.2 \mathrm{~kg} / \mathrm{d}$ (wk 1 postpartum) to stable values between 22 and $23 \mathrm{~kg} / \mathrm{d}$ in wk 7 to 12 postpartum. The postpartum energy balance (EB) followed a similar pattern (Figure 1B), with the lowest values after calving $\left(-46.1 \pm 3.4 \mathrm{MJ}\right.$ of $\left.\mathrm{NE}_{\mathrm{L}} / \mathrm{d}\right)$ and reaching positive values in wk 9 postpartum. At the beginning of lactation, cows met their energetic demands up to $70 \pm 2 \%$, whereas in wk 12 postpartum, the energy intake reached a level of $106 \pm 2 \%$ of the calculated energy requirements.

In period 2, DMI for $\mathrm{R}$ cows decreased from 22.0 to $10.8 \mathrm{~kg} / \mathrm{d}$ within $1 \mathrm{wk}$ of feed restriction and stayed at $10.0 \mathrm{~kg} / \mathrm{d}$ per cow in wk 2 and 3 of restriction $(P<$ $0.001)$. The $\mathrm{R}$ cows experienced a NEB of $-62.7 \mathrm{MJ}$ of $\mathrm{NE}_{\mathrm{L}} / \mathrm{d}$ during the 3 wk of restriction $(P<0.001)$, and only $51 \pm 2 \%$ of their energy requirements was covered.

Within the first week in period $3, \mathrm{C}$ cows had a higher DMI than $\mathrm{R}$ cows. The EB for $\mathrm{R}$ cows returned to positive within wk 2 of realimentation. From wk 3 to 8 , the calculated energy requirement was met by $109 \%$, whereas $\mathrm{C}$ cows had a mean coverage of $\mathrm{EB}$ of $108 \%$.

The mean ACP ( $\mathrm{g} / \mathrm{d}$ per cow) is shown in Figure 1C; it followed a similar pattern to DMI and EB and was affected by treatment in a similar manner to EB.

\section{Milk Yield and Milk Composition}

In period 1, milk yield started with $27.5 \pm 0.7 \mathrm{~kg} / \mathrm{d}$ (mean milk yield of d 4 to 11 postpartum), reached a peak of $39.5 \pm 0.8 \mathrm{~kg} / \mathrm{d}$ in wk 6 postpartum, and declined to $33.7 \pm 1.1 \mathrm{~kg} / \mathrm{d}$ in wk 12 postpartum (Figure 1D). Figure 2A shows the changes of milk fat and 
protein content. Both measures were highest in wk 1 postpartum (fat: $5.48 \pm 0.12 \%$; protein: $4.09 \pm 0.06 \%$ ). The fat to protein ratio (Figure 2B) in period 1 peaked at $1.51 \pm 0.04$ in wk 3 postpartum, and declined to relatively constant values around 1.3 from wk 7 to 12 postpartum. Milk lactose increased from $4.46 \pm 0.02 \%$ in wk 1 postpartum to constant values around $4.77 \pm$ $0.02 \%$ in wk 3 postpartum.

In period $2, \mathrm{R}$ cows showed a moderate but significantly decreased milk yield $(27.4 \pm 0.5 \mathrm{~kg} / \mathrm{d})$ during the $3 \mathrm{wk}$ of feed restriction compared with $\mathrm{C}$ cows $(30.5$ $\pm 0.7 \mathrm{~kg} / \mathrm{d} ; P<0.05)$. Only in wk 1 of period 2 was there a tendency for higher milk fat percentage in $\mathrm{R}$ cows $(P<0.10)$ than in $\mathrm{C}$ cows $(4.63 \pm 0.15 \%$ and 4.38 $\pm 0.11 \%$, respectively). During the remainder of period 2 , no differences were found between the 2 groups. The fat yield calculated over the entire restriction period (Figure 2C) was lower for $\mathrm{R}$ cows compared with $\mathrm{C}$ cows $(1,211 \pm 22$ vs. $1,335 \pm 29 \mathrm{~g} / \mathrm{d})$. Furthermore, in period 2, milk protein concentration was lower $(P<$ $0.05)$ in $\mathrm{R}$ cows than in $\mathrm{C}$ cows $(3.19 \pm 0.03 \%$ and 3.38 $\pm 0.03 \%$, respectively, Figure 2A), and protein yield over the entire restriction period (Figure 2D) was lower in $\mathrm{R}$ cows during period 2 (868 \pm 13 vs. $1,027 \pm 22 \mathrm{~g} / \mathrm{d}$; $P<0.001)$. As a result, the $\mathrm{R}$ cows showed a higher mean fat to protein ratio (Figure $2 \mathrm{~B}$ ) compared with the $\mathrm{C}$ group in period 2 during the entire restriction period $(1.40 \pm 0.03$ vs. $1.30 \pm 0.03 ; P<0.05)$.

During realimentation, in period 3 , milk yield recovered and did not differ between $\mathrm{R}$ and $\mathrm{C}$ cows $(P=$ 0.63). During period 3, no significant differences between the 2 groups were found for milk fat percentage. In wk 1 of period $3, \mathrm{R}$ cows were lower in milk protein content compared with $\mathrm{C}$ cows $(P<0.05)$, and in wk 2 of period 3 , a tendency $(P=0.06)$ still existed for lower protein percentage in the $\mathrm{R}$ cows. The fat to protein ratio in period 3 was not different between $\mathrm{R}$ and $\mathrm{C}$ cows. Feed restriction and subsequent realimentation did not affect lactose content.

\section{BW, BCS, and Ultrasonographic Measurements}

Mean BW (Figure 3A) per cow declined after parturition and remained around $650 \mathrm{~kg}$ from wk 7 to 12 postpartum. In the first week of feed restriction, the $\mathrm{BW}$ of $\mathrm{R}$ cows decreased and was lower than that of $\mathrm{C}$ cows in wk 2 and wk 3 of period $2(P<0.001)$. In period $3, \mathrm{R}$ cows gained $\mathrm{BW}$ and reached a similar BW as $\mathrm{C}$ cows in wk 2 of realimentation. The response to NEB in BW was more intense $(56 \pm 4 \mathrm{~kg})$ in period 2 than in period $1(23 \pm 3 \mathrm{~kg} ; P<0.001)$.

After parturition, BCS (Figure 3B) decreased to 3.05 \pm 0.04 in wk 4 postpartum. In period $2, R$ cows showed decreasing BCS, similar to the loss of BW, that was
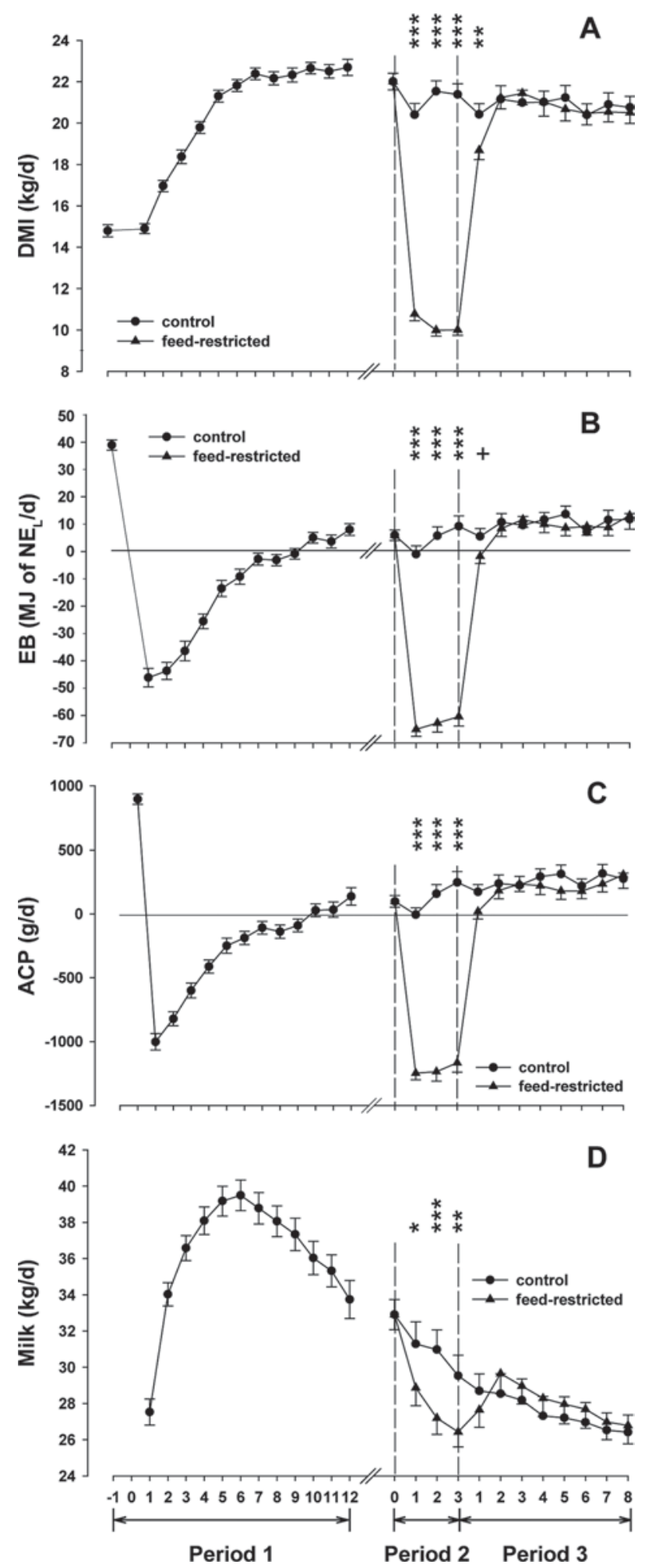

Figure 1. Dry matter intake (A), energy balance (EB; B), available $\mathrm{CP}$ (ACP; C), and milk yield (D) in cows during experimental period 1 (up to wk 12 postpartum), period 2 (3 wk of feed restriction), and period 3 ( 8 wk of realimentation). Data are given as mean values \pm SEM. Differences between the groups are indicated with $+(P<0.10)$, * $(P<0.05)$, ** $(P<0.01)$, and *** $(P<0.001)$. 

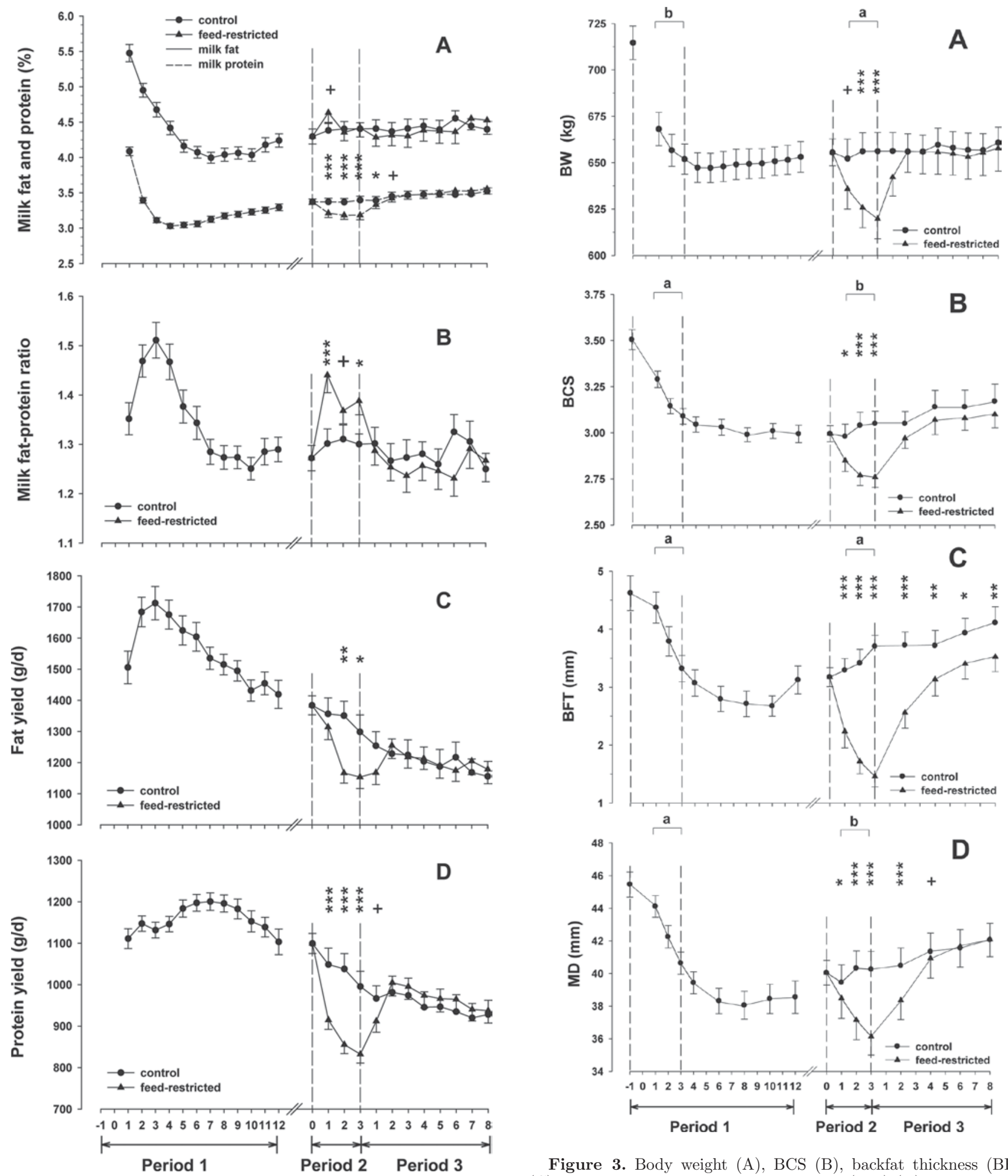

Figure 2. Milk fat and protein content (A), milk fat to protein ratio (B), fat yield (C), and protein yield (D) in cows during experimental period 1 (up to wk 12 postpartum), period 2 (3 wk of feed restriction), and period 3 ( $8 \mathrm{wk}$ of realimentation). Data are given as mean values \pm SEM. Differences between the groups are indicated with $+(P$ $<0.10)$, * $(P<0.05)$, ** $(P<0.01)$, and *** $(P<0.001)$.
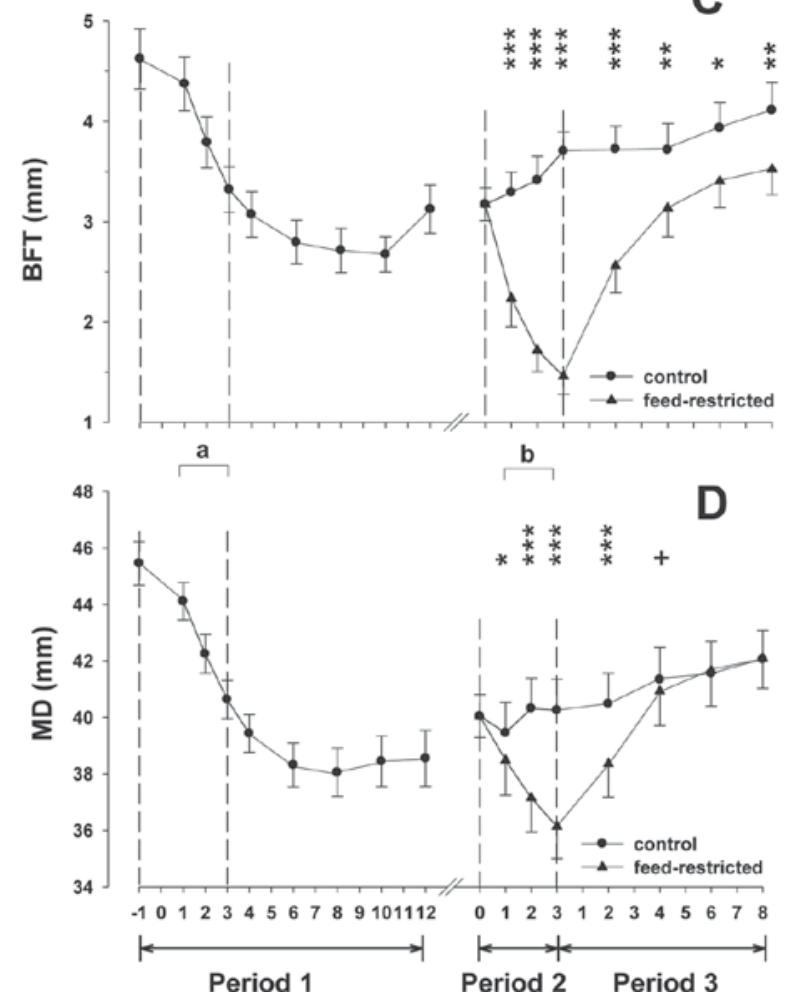

Figure 3. Body weight (A), BCS (B), backfat thickness (BFT) (C), and longissimus dorsi muscle diameter (MD) (D) in cows during experimental period 1 (up to wk 12 postpartum), period 2 (3 wk of feed restriction), and period 3 (8 wk of realimentation). Data are given as mean values \pm SEM. Differences between the groups are indicated with $+(P<0.10), *(P<0.05), * *(P<0.01)$, and $* * *(P<0.001)$. Differences between period 1 (wk 1-3 postpartum) and period 2 are indicated with different letters $(\mathrm{a}, \mathrm{b} ; P<0.05)$. 

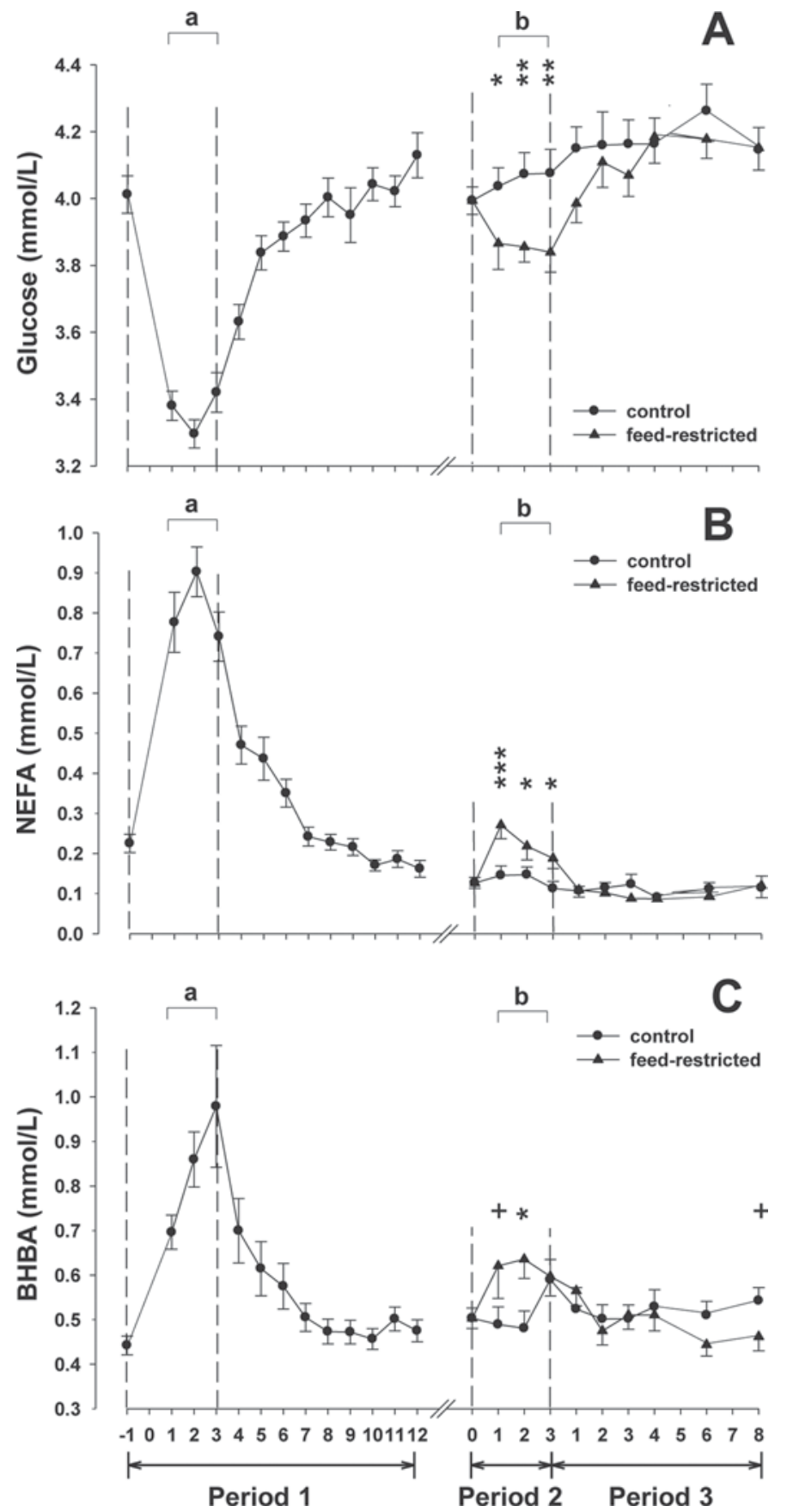

Figure 4. Concentration of plasma glucose (A), NEFA (B), and BHBA (C) in cows during experimental period 1 (up to wk 12 postpartum), period 2 (3 wk of feed restriction), and period 3 (8 wk of realimentation). Data are given as mean values \pm SEM. Differences between the groups are indicated with $+(P<0.10),{ }^{*}(P<0.05)$, ** $(P<0.01)$, and $* * *(P<0.001)$. Differences between period 1 (wk 1 to 3 postpartum) and period 2 are indicated with different letters $(\mathrm{a}, \mathrm{b} ; P<0.05)$

lowest at the end of feed restriction $(P<0.001)$. The $\mathrm{BCS}$ increased in period 3 for $\mathrm{R}$ cows. Cows responded in BCS (Figure 3B) to NEB (Figure 1B) more intensely in period $1(0.34 \pm 0.04)$ than in period $2(0.16 \pm 0.03 ;$ $P<0.01)$.

The BFT (Figure 3C) was lowest in wk 10 postpartum. Within the first week of feed restriction, $\mathrm{R}$ cows had a rapid decline in BFT compared with $\mathrm{C}$ cows $(P$ $<0.001)$. At the end of period $2, \mathrm{R}$ cows had a lower $\mathrm{BFT}(3.7 \pm 0.2 \mathrm{~mm})$ than $\mathrm{C}$ cows $(1.5 \pm 0.2 \mathrm{~mm} ; P$ $<0.001$ ). During realimentation (period 3), BFT in $\mathrm{R}$ cows increased compared with $\mathrm{C}$ cows but did not recover during this period $(P<0.05)$. With regard to BFT, cows responded similarly to a NEB (Figure 1B) in periods $1(0.9 \pm 0.1 \mathrm{~mm})$ and $2(0.8 \pm 0.1 \mathrm{~mm} ; P$ $=0.80)$.

Similar to BFT, MD dropped from the highest value in wk 1 postpartum to the lowest values in wk 8 postpartum and remained unchanged until wk 12 postpartum (Figure 3D). In period 2, the MD of R cows decreased to wk 3 of feed restriction $(P<0.001)$. In period $3, \mathrm{MD}$ increased quickly for $\mathrm{R}$ cows and was unchanged from wk 2 onward. The response of cows to NEB for MD was greater in period 1 than in period $2(3.5 \pm 0.4$ vs. 2.0 $\pm 0.4 \mathrm{~mm} ; P<0.05)$.

\section{Blood Metabolites}

In period 1, plasma glucose concentrations were lowest in wk 2 postpartum (Figure 4A) and increased thereafter. Throughout period 2, mean plasma glucose concentrations were lower in $\mathrm{R}$ cows than in $\mathrm{C}$ cows (3.85 vs. $4.06 \mathrm{mmol} / \mathrm{L} ; P<0.05)$, and increased again in period 3 to levels similar to those of $\mathrm{C}$ cows. The response of cows to NEB for plasma glucose concentrations was greater during period $1(0.65 \pm 0.06$ $\mathrm{mmol} / \mathrm{L})$ than during period $2(0.16 \pm 0.02 \mathrm{mmol} / \mathrm{L}$; $P<0.001)$.

After parturition, plasma NEFA concentrations increased to wk 2 postpartum, and then decreased to wk 12 postpartum (Figure $4 \mathrm{~B}$ ). In period 2 , for $\mathrm{R}$ cows, NEFA concentrations increased within the first week of feed restriction to $0.27 \pm 0.03 \mathrm{mmol} / \mathrm{L}$ and gradually decreased thereafter. In period 3, plasma NEFA concentrations were similar for $\mathrm{R}$ cows and $\mathrm{C}$ cows. The reaction of cows to NEB for plasma NEFA concentrations was more intense in period $1(0.59 \pm 0.05$ $\mathrm{mmol} / \mathrm{L})$ than in period $2(0.08 \pm 0.02 \mathrm{mmol} / \mathrm{L} ; P<$ $0.001)$.

Concentrations of BHBA increased to wk 3 postpartum. Thereafter, BHBA decreased to a steady concentration of approximately $0.50 \mathrm{mmol} / \mathrm{L}$ from wk 7 to 12 postpartum (Figure 4C). During feed restriction in period 2, BHBA concentrations peaked in wk 2 at which time BHBA concentrations were higher for $\mathrm{R}$ cows than $\mathrm{C}$ cows $(0.64 \pm 0.04$ vs. $0.48 \pm 0.04 \mathrm{mmol} / \mathrm{L} ; P<$ 0.05). In period 3 , no differences between $\mathrm{R}$ and $\mathrm{C}$ cows 
Table 2. Occurrence (number) of health disorders during experimental periods ${ }^{1}$

\begin{tabular}{|c|c|c|c|c|c|c|c|}
\hline Health disorder & Period 1 & \multicolumn{3}{|c|}{ Period 2} & \multicolumn{3}{|c|}{ Period 3} \\
\hline Mastitis and other udder-related problems & 8 & 0 & 2 & & 4 & 1 & \\
\hline Claw problems & 9 & 2 & 0 & & 0 & 2 & \\
\hline Milk fever & 3 & 0 & 0 & & 0 & 0 & \\
\hline Total & 22 & 2 & 2 & 0.50 & 4 & 3 & 0.35 \\
\hline
\end{tabular}

${ }^{1}$ Period 1 = wk 1 to 12 postpartum; period $2=$ feed restriction for 3 wk starting at 100 DIM; period $3=$ realimentation period for 8 wk after period 2. $\mathrm{R}=$ feed-restricted cows; $\mathrm{C}=$ control cows.

${ }^{2} P$-values $<0.05$ indicate significant differences between $\mathrm{R}$ and $\mathrm{C}$ cows.

were observed for BHBA concentrations. In period 1, cows responded more intensely $(0.41 \pm 0.07 \mathrm{mmol} / \mathrm{L})$ in BHBA concentrations to NEB than in period $2(0.13$ $\pm 0.03 \mathrm{mmol} / \mathrm{L} ; P<0.01)$.

\section{Animal Health}

Table 2 gives an overview of the number and type of health disorders in the different experimental periods. Based on the sum of disorders, diseases were more frequent $(P<0.05)$ in period 1 than in period 2 , but $\mathrm{R}$ and $\mathrm{C}$ cows did not differ during feed restriction $(P=$ $0.50)$ and realimentation $(P=0.35)$.

\section{DISCUSSION}

Negative energy balance can be responsible for health disorders (e.g., fertility problems, infectious diseases; Bertoni et al., 2009). On the other hand, health problems (e.g., digestive or locomotive problems) can be a trigger for NEB and may affect the NEB negatively in early lactating cows. Furthermore, the incidence of disease occurrence is closely related to high-yielding dairy cows in the transition period. This was observed in the present study, where more health problems were observed in early than in later lactation, when milk yield and metabolic stress were lower. The present study shows that metabolically more stressed cows during the NEB in early lactation simultaneously have more health disorders compared with cows experiencing a higher deliberately induced NEB with lower responses in metabolism and fewer health problems.

\section{NEB During and Following Early Lactation}

The evolution of DMI and EB after parturition in the present study followed expected patterns. After parturition, the EB decreased within a week to a nadir of $-46 \mathrm{MJ}$ of $\mathrm{NE}_{\mathrm{L}} / \mathrm{d}$, which supports the nadir observed by Kessel et al. (2008), who conducted their study at the same research station, using the experimental herd. The total DMI supported the reports of Ingvartsen and Andersen (2000) and Kessel et al. (2008), and began at about $15 \mathrm{~kg} / \mathrm{d}$ in the first week postpartum, which was higher than that reported by Ingvartsen and Andersen (2000). A plateau of DMI was reached from wk 7 postpartum onward, showing an adaptive performance of the cows, because the peak of DMI generally lags until 10 to $14 \mathrm{wk}$ postpartum in early lactating dairy cows (NRC, 2001). Jorritsma et al. (2003) reported that the balance between energy from feed intake and energy requirements was attained at approximately 10 wk postpartum, which was supported by the present study, in which a positive EB was achieved in wk 9 postpartum.

The EB during the deliberately induced NEB in wk 14 postpartum decreased as suddenly as the lactationinduced NEB after parturition and achieved a nadir within 1 wk from the start of feed restriction. During the first week of the deliberately induced NEB, a $\mathrm{NEB}$ of $-65 \mathrm{MJ}$ of $\mathrm{NE}_{\mathrm{L}} / \mathrm{d}$ was achieved. In addition, the deliberately induced NEB remained at a level of $-63 \mathrm{MJ}$ of $\mathrm{NE}_{\mathrm{L}} / \mathrm{d}$ for $3 \mathrm{wk}$, whereas the NEB in early lactation diminished gradually after its nadir in wk 1 postpartum. This level of the deliberately induced NEB by feed restriction supported the induced NEB in other studies (Velez and Donkin, 2005; Carlson et al., 2006). The deliberately induced NEB by feed restriction was induced by reduction of DMI and energy density of the PMR. The suitability of the method was shown previously (Capuco et al., 2001).

\section{Production Responses}

From an evolutionary point of view, it is reasonable that the priority of milk production for ruminants is highest after parturition when the offspring depends on milk as the exclusive feed source (Morrill et al., 1981). The peak of milk yield was reached in wk 6 postpartum in the present study, which supports observations 
from the NRC (2001) and Piepenbrink et al. (2004), indicating milk production peaks between 4 and $8 \mathrm{wk}$ postpartum.

Surprisingly, the decline in milk yield during the deliberately induced NEB in the present study was only about $3 \mathrm{~kg}(\sim 10 \%)$. This was a significant decrease compared with that in the $\mathrm{C}$ cows, although less than the decrease of about $20 \%$ in milk yield in studies with a comparable extent of induced NEB to the present study (Velez and Donkin, 2005; Carlson et al., 2006). Among the level of the NEB induced by feed restriction, its initiation and duration must be considered in the evaluation of effects on milk production. In the present study, feed restriction lasted 3 wk starting at 100 DIM, whereas feed restriction lasted only $5 \mathrm{~d}$ in the study of Carlson et al. (2006), but began at 132 DIM. Furthermore, age, breed type, and genetic merit of the dairy cow may influence a cow's response to a deliberately induced energy deficiency.

During realimentation, milk yield for energy-restricted cows in the present study fully recovered to the level of the control animals. Based on calculated EB, the ad libitum feeding in this period resulted in an energy supply above cows' requirements. Besides milk yield, milk composition was affected by lactation stage and energy supply in the present study. Milk fat and protein content in early lactation decreased with the simultaneously increasing milk yield supporting Zanartu et al. (1983). During the feed restriction period in the present study, milk fat was not different in feed restriction, supporting Velez and Donkin (2005) and Carlson et al. (2006), despite a comparable NEB induced by feed restriction.

Milk protein decreased due to the energy deficiency and the simultaneous reduced protein supply during the feed restriction period. These results support studies of Röhrmoser and Kirchgessner (1982) and Carlson et al. (2006) and reflect the limited intake of feed protein. Furthermore, microbial protein synthesis in the rumen is dependent on the energy supply. Derived from milk solids, the fat to protein ratio in milk can be used as a tool indicating NEB. Heuer et al. (1999) recommend threshold values between 1.35 and 1.50 , beyond which individual cows are regarded to be at higher risk for energy deficiency. When 1.35 was considered as the lower threshold, dairy cows in the present study were above this level in the first 5 wk of lactation and during the feed restriction period. The fat to protein ratio in milk partly seems a suitable instrument to detect a NEB in early and mid lactation. In contrast to milk fat and protein contents, lactose content seems to be very stable in mid and late lactation and was not affected in the present study, supporting Velez and Donkin (2005) and Carlson et al. (2006), where feed restriction did not alter milk lactose content.

\section{Changes of $B W, B C S, B F T, M D$, and Blood Metabolites}

In early lactation, mobilization of adipose tissue was associated with decreasing BW; it occurred simultaneously with a rapid increase of DMI. The loss of BW concomitant to the increase of DMI in early lactation was observed in a study of Liefers et al. (2003). During feed restriction, the loss of $\mathrm{BW}$ is a consequence of the reduced DMI and the loss of gut fill (NRC, 2001). Yet, the amount of mobilized fat can be larger than the loss of BW because the depleted body mass is partially replaced by water in the tissues (Schröder and Staufenbiel, 2006).

After a deliberately induced NEB, BW recovered in feed-restricted cows within 2 wk of realimentation, supporting Agenäs et al. (2003) who found a quick recovery of BW within $4 \mathrm{~d}$ of refeeding and Chelikani et al. (2004) after $24 \mathrm{~h}$ of refeeding after feed deprivation for $48 \mathrm{~h}$. The quick increase of BW may be attributed to the increased gut fill during the refeeding period, not only to the recovery of body reserves.

To quantify the actual changes in body reserves during periods of NEB, BCS, MD, and BFT were evaluated in the present study. The BCS can mirror the nutritional status in dairy cows as it reflects changes in the subcutaneous fat layer, but BCS is influenced by subjective factors (Bruckmaier et al., 1998a). According to those authors, changes of the longissimus dorsi MD and BFT parallel those of BCS and reflect alterations of whole-body fat content and muscle mass. The decrease in BFT during the restriction period was comparable to the mobilization in early lactation $(0.8 \pm 0.1$ vs. 0.9 $\pm 0.1 \mathrm{~mm})$, whereas changes in MD were lower $(2.0$ \pm 0.4 vs. $3.5 \pm 0.4 \mathrm{~mm}$ ) than in early postpartum. Furthermore, MD recovered totally in the realimentation period, whereas BFT did not recover until the end of the experiment. Björntorp et al. (1982) showed that the replenishment of lipid stores after feed restriction takes longer than refilling protein stores. The priority of body protein is maintained by limited proteolysis via endocrine control during stages of a NEB (Hocquette et al., 2007).

Plasma metabolites responded to the deliberately induced NEB at the same time as to the lactation NEB, but the extent of changes was lesser. Plasma glucose concentration decreased in the first 2 wk after parturition. According to previous studies (Baxter et al., 1956; Blum et al., 1983), this can be interpreted as a consequence of the high demand for this substrate, especially 
for the synthesis of lactose. The homeostatic control of blood glucose concentration in mid lactation was not affected by a partial energy restriction in the study of Carlson et al. (2006). In contrast, in the present study, plasma glucose concentration decreased during the feed restriction period. Glucose concentration was lowered by $0.2 \mathrm{mmol} / \mathrm{L}$ for feed-restricted cows $(3.9$ vs. $4.1 \mathrm{mmol} / \mathrm{L}$ ), despite the high NEB of almost $50 \%$ of requirements. Nevertheless, energy-restricted cows after 100 DIM did not become as hypoglycemic as in early lactation.

During NEB in early lactation, body fat is mobilized and leads to increased levels of NEFA (Kessel et al., 2008; van Dorland et al., 2009). In contrast, the even greater NEB induced by feed restriction following early lactation in the present study resulted in an increase of NEFA concentration to a maximum of $0.27 \mathrm{mmol} / \mathrm{L}$ that was still below the concentration of $0.9 \mathrm{mmol} / \mathrm{L}$ observed in wk 2 postpartum. Carlson et al. (2006) found that plasma NEFA concentrations in feed-restricted cows (132 DIM) were elevated to a much lesser degree compared with the observations in early lactation.

The present study showed the highest values for BHBA during the NEB in early lactation $(0.98 \mathrm{mmol} / \mathrm{L}$ in wk 3 postpartum), supporting Doepel et al. (2002) who showed that plasma BHBA concentrations peak later than NEFA concentrations. During the NEB deliberately induced by feed restriction following early lactation in the present study, $\mathrm{R}$ cows showed only a small change in BHBA concentration compared with control cows (0.6 vs. $0.5 \mathrm{mmol} / \mathrm{L})$. In Carlson et al. (2006), an energy restriction of $50 \%$ did not increase BHBA concentration in feed-restricted cows. This can be explained by the smaller increase in the concentration of NEFA that serve as a substrate for ketone body production.

\section{CONCLUSIONS}

In contrast to the milk production during early lactation (Bauman and Currie, 1980), during which cows have more metabolic problems, a deliberately induced NEB at around 100 DIM resulted in an immediate but small decline of milk yield, accompanied by high losses of body reserves. In addition, the marginal changes of metabolic measures during a deliberately induced NEB by feed restriction following early lactation were within the range observed for metabolically nonchallenged cows. Therefore, the hypothesis that responses of dairy cows in performance and metabolites to a NEB in early and following early lactation are different was confirmed by the observations made in the present study. Studies on endocrine regulatory mechanisms and changes in liver metabolism designed to explain the present findings are in progress.

\section{ACKNOWLEDGMENTS}

The authors thank Yolande Zbinden (Veterinary Physiology, University of Bern) for the blood plasma analyses. The mentoring of the Graduate School (Graduate Center Weihenstephan) of the Technical University of Munich (TUM-GS) during the doctoral study of J. Gross is acknowledged.

\section{REFERENCES}

Agenäs, S., K. Dahlborn, and K. Holtenius. 2003. Changes in metabolism and milk production during and after feed deprivation in primiparous cows selected for different milk fat content. Livest. Prod. Sci. 83:153-164.

Bauman, D. E., and W. B. Currie. 1980. Partitioning of nutrients during pregnancy and lactation: A review of mechanisms involving homeostasis homeorhesis. J. Dairy Sci. 63:1514-1529.

Baxter, C. F., M. Kleiber, and A. L. Black. 1956. The blood precursors of lactose as studied with ${ }^{14} \mathrm{C}$-labeled metabolites in intact dairy cows. Biochim. Biophys. Acta 21:277-285.

Bertoni, G., E. Trevisi, and R. Lombardelli. 2009. Some new aspects of nutrition, health conditions and fertility of intensively reared dairy cows. Ital. J. Anim. Sci. 8:491-518.

Björntorp, P., S. Edström, J. G. Kral, K. Lundholm, E. Presta, D. Walks, and M.-U. Yang. 1982. Refeeding after fasting in the rat: Energy substrate fluxes and replenishment of energy stores. Am. J. Clin. Nutr. 36:450-456.

Blum, J. W., P. Kunz, H. Leuenberger, K. Gautschi, and M. Keller. 1983. Thyroid hormones, blood plasma metabolites and haematological parameters in relationship to milk yield in dairy cows. Anim. Prod. 36:93-104.

Bruckmaier, R. M., L. Gregoretti, F. Jans, D. Faissler, and J. W. Blum. 1998a. Longissimus dorsi muscle diameter, backfat thickness, body condition scores and skinfold values related to metabolic and endocrine traits in lactating dairy cows fed crystalline fat or free fatty acids. Zentralbl. Veterinarmed. A 45:397-410.

Bruckmaier, R. M., E. Lehmann, D. Hugi, H. M. Hammon, and J. W. Blum. 1998b. Ultrasonic measurement of longissimus dorsi muscle and backfat, associated with metabolic and endocrine traits, during fattening of intact and castrated male cattle. Livest. Prod. Sci. 53:123-134.

Butler, S. T., A. L. Marr, S. H. Pelton, R. P. Radcliff, M. C. Lucy, and W. R. Butler. 2003. Insulin restores GH responsiveness during lactation-induced negative energy balance in dairy cattle: Effects on expression of IGF-I and GH receptor 1A. J. Endocrinol. 176:205-217.

Cannon, W. B. 1929. Organization for physiological homeostasis. Physiol. Rev. 9:399-431.

Capuco, A. V., D. L. Wood, T. H. Elsasser, S. Kahl, R. A. Erdman, C. P. Van Tassell, A. Lefcourt, and L. S. Piperova. 2001. Effect of somatotropin on thyroid hormones and cytokines in lactating dairy cows during ad libitum and restricted feed intake. J. Dairy Sci. $84: 2430-2439$.

Carlson, D. B., N. B. Litherland, H. M. Dann, J. C. Woodworth, and J. K. Drackley. 2006. Metabolic effects of abomasal L-carnitine infusion and feed restriction in lactating Holstein cows. J. Dairy Sci. 89:4819-4834.

Chelikani, P. K., J. D. Ambrose, D. H. Keisler, and J. J. Kennelly. 2004. Effect of short-term fasting on plasma concentrations of lep- 
tin and other hormones and metabolites in dairy cattle. Domest. Anim. Endocrinol. 26:33-48.

Doepel, L., H. Lapierre, and J. J. Kennelly. 2002. Peripartum performance and metabolism of dairy cows in response to prepartum energy and protein intake. J. Dairy Sci. 85:2315-2334.

Edmonson, A. J., I. J. Lean, L. D. Weaver, T. Farver, and G. Webster. 1989. A body condition scoring chart for Holstein dairy cows. J. Dairy Sci. 72:68-78.

GfE (German Society of Nutrition Physiology). 2001. Empfehlungen zur Energie- und Nährstoffversorgung der Milchkühe und Aufzuchtrinder, Ausschuss für Bedarfsnormen der Gesellschaft für Ernährungsphysiologie. DLG-Verlag, Frankfurt am Main, Germany.

Heuer, C., Y. H. Schukken, and P. Dobbelaar. 1999. Postpartum body condition score and results from the first test day milk as predictors of disease, fertility, yield, and culling in commercial dairy herds. J. Dairy Sci. 82:295-304.

Hocquette, J. F., S. Tesseraud, I. Cassar-Malek, Y. Chilliard, and I Ortigues-Marty. 2007. Responses to nutrients in farm animals: Implications for production and quality. Animal 1:1297-1313.

Ingvartsen, K. L., and J. B. Andersen. 2000. Integration of metabolism and intake regulation: A review focusing on periparturient animals. J. Dairy Sci. 83:1573-1597.

Jorritsma, R., T. Wensing, T. A. M. Kruip, P. L. A. M. Vos, and J. P. T. M. Noordhuizen. 2003. Metabolic changes in early lactation and impaired reproductive performance in dairy cows. Vet. Res. $34: 11-26$.

Kessel, S., M. Stroehl, H. H. D. Meyer, S. Hiss, H. Sauerwein, F. J. Schwarz, and R. M. Bruckmaier. 2008. Individual variability in physiological adaptation to metabolic stress during early lactation in dairy cows kept under equal conditions. J. Anim. Sci. 86:2903-2912.

Liefers, S. C., R. F. Veerkamp, M. F. W. te Pas, C. Delavaud, Y. Chilliard, and T. van der Lende. 2003. Leptin concentration in re- lation to energy balance, milk yield, intake, live weight, and estrus in dairy cows. J. Dairy Sci. 86:799-807.

Morrill, J. L., A. D. Dayton, and K. C. Behnke. 1981. Increasing consumption of dry feed by young calves. J. Dairy Sci. 64:22162219.

Naumann, K., R. Bassler, R. Seibold, and C. Barth. 2000. Die chemische Untersuchung von Futtermitteln, Methodenbuch Bd. III, Verband Deutscher Landwirtschaftlicher Untersuchungs- und Forschungsanstalten. VDLUFA-Press, Darmstadt, Germany.

NRC. 2001. Nutrient Requirements of Dairy Cattle. 7th rev. ed. National Academic Press, Washington, DC.

Piepenbrink, M. S., A. L. Marr, M. R. Waldron, W. R. Butler, T. R. Overton, M. Vázquez-Anón, and M. D. Holt. 2004. Feeding 2-hydroxy-4-(methylthio)-butanoic acid to periparturient dairy cows improves milk production but not hepatic metabolism. J. Dairy Sci. 87:1071-1084

Röhrmoser, G., and M. Kirchgessner. 1982. Milk yield and milk ingredients of cows with undersupply in energy followed by realimentation. Zuchtungskunde 54:276-287.

Schröder, U. J., and R. Staufenbiel. 2006. Invited review: Methods to determine body fat reserves in the dairy cow with special regard to ultrasonographic measurement of backfat thickness. J. Dairy Sci. 89:1-14

van Dorland, H. A., S. Richter, I. Morel, M. G. Doherr, N. Castro, and R. M. Bruckmaier. 2009. Variation in hepatic regulation of metabolism during the dry period and in early lactation in dairy cows. J. Dairy Sci. 92:1924-1940.

Velez, J. C., and S. S. Donkin. 2005. Feed restriction induces pyruvate carboxylase but not phosphoenolpyruvate carboxykinase in dairy cows. J. Dairy Sci. 88:2938-2948.

Zanartu, D., C. E. Polan, L. E. Ferreri, and M. L. McGilliard. 1983. Effect of stage of lactation and varying available energy intake on milk production, milk composition, and subsequent tissue enzymic activity. J. Dairy Sci. 66:1644-1652. 